\title{
INTERDEPENDENT DURATIONS IN JOINT RETIREMENT
}

Bo Honoré and Áureo de Paula

CRR WP 2011-5

Date Released: February 2011

Date Submitted: January 2011

\author{
Center for Retirement Research at Boston College \\ Hovey House \\ 140 Commonwealth Avenue \\ Chestnut Hill, MA 02467 \\ Tel: 617-552-1762 Fax: 617-552-0191 \\ http://crr.bc.edu
}

Bo Honoré is Director of the Gregory C. Chow Econometric Research Program at Princeton University. Áureo de Paula is Assistant Professor of Economics at the University of Pennsylvania. The research reported herein was pursuant to a grant from the U.S. Social Security Administration (SSA) funded as part of the Retirement Research Consortium (RRC). The findings and conclusions expressed are solely those of the authors and do not represent the views of SSA, any agency of the federal government, the RRC, Princeton University, University of Pennsylvania, or Boston College.

(C) 2011, by Bo Honoré and Áureo de Paula. All rights reserved. Short sections of text, not to exceed two paragraphs, may be quoted without explicit permission provided that full credit, including $($ ) notice, is given to the source. 


\begin{abstract}
About the Sandell Grant Program
This paper received funding from the Steven H. Sandell Grant Program for Junior Scholars in Retirement Research. Established in 1999, the Sandell program's purpose is to promote research on retirement issues by scholars in a wide variety of disciplines, including actuarial science, demography, economics, finance, gerontology, political science, psychology, public administration, public policy, sociology, social work, and statistics. The program is funded through a grant from the Social Security Administration (SSA). For more information on the Sandell program, please visit our website at http://crr.bc.edu/opportunities/steven_h._sandell_ grant_program_2.html, send e-mail to crr@bc.edu, or call Marina Tsiknis at (617) 552-1092.
\end{abstract}

\title{
About the Center for Retirement Research
}

The Center for Retirement Research at Boston College, part of a consortium that includes parallel centers at the University of Michigan and the National Bureau of Economic Research, was established in 1998 through a grant from the Social Security Administration. The Center's mission is to produce first-class research and forge a strong link between the academic community and decision-makers in the public and private sectors around an issue of critical importance to the nation's future. To achieve this mission, the Center sponsors a wide variety of research projects, transmits new findings to a broad audience, trains new scholars, and broadens access to valuable data sources.

\author{
Center for Retirement Research at Boston College \\ Hovey House \\ 140 Commonwealth Avenue \\ Chestnut Hill, MA 02467 \\ phone: 617-552-1762 fax: 617-552-0191 \\ e-mail: crr@bc.edu \\ crr.bc.edu
}

Affiliated Institutions:

The Brookings Institution

Massachusetts Institute of Technology

Syracuse University

Urban Institute 


\begin{abstract}
In this paper, we use a novel duration model to study joint retirement in married couples using the Health and Retirement Study. Whereas conventionally used models cannot account for joint retirement, our model admits joint retirement with positive probability and nests the traditional proportional hazards model. In contrast to other statistical models for simultaneous durations, it is based on Nash bargaining and is interpretable as an economic behavior model. Our estimation strategy relies on indirect inference.
\end{abstract}




\section{Introduction and Related Literature}

This paper investigates the determinants of joint retirement decisions in couples. A majority of retirees are married and many studies indicate that a significant proportion of individuals retires within a year of their spouse. Articles documenting joint retirement of couples (and datasets employed) include Hurd (1990) (New Beneficiary Survey); Blau (1998) (Retirement History Study); Gustman and Steinmeier (2000) (National Longitudinal Survey of Mature Women); Michaud (2003) and Gustman and Steinmeier (2004) (Health and Retirement Study); and Banks, Blundell, and Casanova Rivas (2007) (English Longitudinal Study of Ageing). Even though this is especially the case for couples closer in age, a spike in the distribution of retirement time differences at zero typically exists for most couples, regardless of the age difference. This is illustrated in Figure 1.

The spike in the distribution of the difference in the retirement dates for husbands and wives in Figure 1 suggests that many couples retire simultaneously. There are at least two distinct explanations for such a phenomenon. One is that husband and wife receive correlated shocks (observable or not), driving them to retirement at similar times. The other is that retirement is jointly decided, reflecting taste interactions of both members of the couple.

The distinction between these two drivers of joint retirement (which are not mutually exclusive) parallels the categorization by Manski (1993) of correlated and endogenous effects in the social interactions literature, and is similar to the distinction between seemingly unrelated regressions and simultaneous equations. There, as in this article, discerning these two sources of correlation in outcomes is relevant for analytical and policy reasons. For example, if the estimated model does not allow for the joint decision by the couple, then the estimate of the effect of a retirement-inducing shock will be biased if the retirement times are indeed chosen jointly. Such spillover effects invalidate, for instance, the commonly employed Stable Unit Treatment Value Assumption (SUTVA) taken in the treatment effects literature, preventing the clear separation of direct and indirect effects occurring through feedback to the partner's retirement decision [e.g., Burtless (1990)]. Furthermore, the multiplier effect 
induced by the endogenous, direct effect of husband on wife or vice-versa is an important conduit for policy. The quantification of its relative importance is hence paramount for both methodological and substantive reasons.

Unfortunately, standard econometrics duration models are not suitable to analyze joint durations with simultaneity of the kind that we have in mind, and an important contribution of this paper is therefore the specification of an econometric duration model that allows for simultaneity [see also de Paula (2009) and Honoré and de Paula (2010)].

The broader literature on retirement is abundant and a number of papers focusing on retirement decisions in a multi-person household have appeared in the last 20 years. Hurd (1990) presents one of the early documentations of the joint retirement phenomenon. Later papers confirming the phenomenon and further characterizing the correlates of joint retirement are Blau (1998); Michaud (2003); Coile (2004a); Banks, Blundell, and Casanova Rivas (2007). Gustman and Steinmeier (2000) and Gustman and Steinmeier (2004) work with a dynamic non-unitary structural mode $\bigsqcup^{1}$ for husband-wife retirement and focus on Nash solutions to the joint retirement decision.2 Gustman and Steinmeier (2009) present a richer (non-unitary) structural model with a solution concept that deviates from Nash Equilibrium and is guaranteed to exist and be unique. Michaud and Vermeulen (forthcoming) estimate a version of the "collective" model [see Chiappori (1992)] where (static) labor force participation decisions by husband and wife are repeatedly observed from a panel (i.e., the HRS). Casanova Rivas (2010) recently suggests a detailed unitary structural dynamic model of joint retirement. Coile (2004b) presents statistical evidence on health shocks and retirement decision by the couple and Blau and Gilleskie (2004) present a structural model also focusing on health outcomes and retirement in the couple.

In our analysis, we assume that retirement decisions are made through Nash Bargaining on the retirement date. Though this also leads to Pareto efficient outcomes, it imposes

\footnotetext{
${ }^{1}$ See Browning, Chiappori, and Lechene (2006) for a characterization of unitary and non-unitary household models.

${ }^{2}$ When more than one equilibrium is possible, they use an equilibrium selection rule that selects the Pareto dominant equilibrium or, in case no equilibrium is dominant, the equilibrium where retirement by at least one household member happens earliest (see, e.g., Gustman and Steinmeier (2000), pp. 515, 520).
} 
more structure than Casanova Rivas (2010) or Michaud and Vermeulen (forthcoming) [see Chiappori (1992) and Chiappori, Donni, and Komunjer (2010)]. Our model is a variation of a recently developed model (Honoré and de Paula (2010)) which extends well-known duration models to a (non-cooperative) strategic stopping game, where endogenous and correlated effects can be disentangled and interpreted (see also de Paula (2009) for a related analysis) $!^{3}$ As such it is close to traditional duration models in the statistics and econometrics literature. Our model extends the usual statistical framework in a way that allows for joint termination of simultaneous spells with positive probability. In the usual hazard modeling tradition, this property does not arise. It is nonetheless essential to model joint retirement behavior. One can appeal to existing statistical models to address this issue as done by An, Christensen, and Gupta (2004) in the analysis of joint retirement in Denmark, but parameter estimates cannot be directly interpretable in terms of the decision process by the couple. The framework presented in this paper directly corresponds to an economic model of decision-making by husband and wife and consequently can be more easily interpreted in light of such model. To estimate our model, we resort to indirect inference (Smith (1993); Gourieroux, Monfort, and Renault (1993); and Gallant and Tauchen (1996)), using as auxiliary models standard duration models and ordered models, as suggested in Honoré and de Paula (2010) for a similar model. (For an earlier application of indirect inference in a duration context, see Magnac, Robin, and Visser (1995)).

The remainder of this paper proceeds as follows. Section 2 describes our model and the empirical strategy for its estimation. In Section 3 we briefly describe the data and subsequently discuss our results in Section 4. We conclude in Section 5 .

\footnotetext{
${ }^{3}$ In fact, our model estimates are obtained using auxiliary models that are interpretable in terms of the (non-cooperative game-theoretic) model in Honoré and de Paula (2010), which does not impose Pareto efficiency and equilibrium uniqueness.
} 


\section{Model and Empirical Strategy}

In our model, spouse $i$ receives a utility flow of $K_{i}$ before retirement. After retirement, the utility flow is given by $Z(s) \varphi_{i} \delta\left(s, t_{j}\right) e^{-\rho s}$ at time $s$. The function $Z(\cdot)$ is a smooth increasing function such that $Z(0)=0$. The factor $\varphi_{i}=\varphi\left(x_{i}\right)$ is a positive function of individual observable covariates. Time is discounted at the rate $\rho>0$ and $\delta\left(s, t_{j}\right)=(\delta-1) \mathbf{1}\left(s \geq t_{j}\right)+1$ where $\delta>1$ and $t_{j}$ is the retirement date for spouse $j$, representing the effect of spouse $j$ 's retirement on $i$ 's utility flow from retirement. This structure is similar to the one defined in Honoré and de Paula (2010): if $\delta=1$, we obtain a standard proportional hazards model for the time until retirement. Time is measured in terms of "family age," which is set to zero when the oldest partner in the couple reaches 60 years-old. Retirement timing is obtained as the solution to the Nash bargaining problem [Nash (1950), see also Zeuthen (1930)]:

$$
\begin{aligned}
\max _{t_{1}, t_{2}}\left(\int_{0}^{t_{1}} K_{1} e^{-\rho s} d s\right. & \left.+\int_{t_{1}}^{\infty} Z(s) \varphi_{1} \delta\left(s \geq t_{2}\right) e^{-\rho s} d s-A_{1}\right) \times \\
& \left(\int_{0}^{t_{2}} K_{2} e^{-\rho s} d s+\int_{t_{2}}^{\infty} Z(s) \varphi_{2} \delta\left(s \geq t_{1}\right) e^{-\rho s} d s-A_{2}\right)
\end{aligned}
$$

where $A_{1}$ and $A_{2}$ are the threat points for spouses 1 and 2, respectively. In our estimation, we set $A_{i}$ equal to a multiple of the utility spouse $i$ would obtain if spouse $j$ never retired. Note that the first term can be further simplified to

$$
\begin{aligned}
& \left(\left.K_{1} \frac{-e^{-\rho s}}{\rho}\right|_{0} ^{t_{1}}+\varphi_{1} \int_{t_{1}}^{\infty} Z(s) e^{-\rho s} d s+\varphi_{1}(\delta-1) \int_{\max \left\{t_{1}, t_{2}\right\}}^{\infty} Z(s) e^{-\rho s} d s-A_{1}\right) \\
= & \left(K_{1} \rho^{-1}\left(1-e^{-\rho t_{1}}\right)+\varphi_{1} \widetilde{Z}\left(t_{1}\right)+\varphi_{1}(\delta-1) \widetilde{Z}\left(\max \left\{t_{1}, t_{2}\right\}\right)-A_{1}\right)
\end{aligned}
$$

where

$$
\widetilde{Z}(t)=\int_{t}^{\infty} Z(s) e^{-\rho s} d s
$$

and hence

$$
\widetilde{Z}^{\prime}(t)=-Z(t) e^{-\rho t}
$$

An analogous simplification applies to the second term. In the absence of an interaction effect $(\delta=1)$, a Weibull baseline hazard for the proportional hazard model would correspond to

$$
Z(t ; \alpha)=t^{a}
$$


and consequently

$$
\begin{aligned}
\widetilde{Z}(t ; \alpha) & =\int_{t}^{\infty} s^{\alpha} e^{-\rho s} d s \\
& =\left(\frac{1}{\rho}\right)^{\alpha+1} \Gamma(\alpha+1, \rho t)
\end{aligned}
$$

where the upper incomplete gamma function is defined by

$$
\Gamma(\alpha, x)=\int_{x}^{\infty} s^{\alpha-1} e^{-s} d s
$$

This expression can be further manipulated by noting that if the random variable $X$ is Gamma distributed with parameters $\alpha$ and $\beta=1$

$$
\begin{aligned}
\bar{F}_{\Gamma(\alpha, 1)}(x) & =P(X>x) \\
& =\frac{1}{\Gamma(\alpha)} \int_{x}^{\infty} s^{\alpha-1} e^{-s} d s=\frac{\Gamma(\alpha, x)}{\Gamma(\alpha)} .
\end{aligned}
$$

Consequently,

$$
\begin{aligned}
\widetilde{Z}(t ; \alpha) & =\left(\frac{1}{\rho}\right)^{\alpha+1} \Gamma(\alpha+1, \rho t) \\
& =\left(\frac{1}{\rho}\right)^{\alpha+1} \Gamma(\alpha+1) \bar{F}_{\Gamma(\alpha+1,1)}(\rho t)
\end{aligned}
$$

which is useful since both $\Gamma(\cdot)$ and $\bar{F}_{\Gamma(\cdot, 1)}(\cdot)$ are preprogrammed in many languages or softwares commonly used.

In summary, the objective function is given by

$$
\begin{aligned}
N\left(t_{1}, t_{2}\right)=\left(K_{1} \rho^{-1}\left(1-e^{-\rho t_{1}}\right)+\varphi_{1} \widetilde{Z}\left(t_{1}\right)+\varphi_{1}(\delta-1) \widetilde{Z}\left(\max \left\{t_{1}, t_{2}\right\}\right)-A_{1}\right) \times \\
\left(K_{2} \rho^{-1}\left(1-e^{-\rho t_{2}}\right)+\varphi_{2} \widetilde{Z}\left(t_{2}\right)+\varphi_{2}(\delta-1) \widetilde{Z}\left(\max \left\{t_{1}, t_{2}\right\}\right)-A_{2}\right)
\end{aligned}
$$

If spouses retire sequentially, the objective function first order conditions are obtained as follows. Assuming $t_{1}<t_{2}$ and taking derivatives with respect to $t_{1}$ we get:

$$
\left(K_{1} e^{-\rho t_{1}}-Z\left(t_{1}\right) \varphi_{1} e^{-\rho t_{1}}\right)\left(\int_{0}^{t_{2}} K_{2} e^{-\rho s} d s+\int_{t_{2}}^{\infty} Z(s) \varphi_{2} \delta\left(s \geq t_{1}\right) e^{-\rho s} d s-A_{2}\right)=0 .
$$

This implies that

$$
K_{1}=Z\left(t_{1}\right) \varphi_{1}
$$


or

$$
\int_{0}^{t_{2}} K_{2} e^{-\rho s} d s+\int_{t_{2}}^{\infty} Z(s) \varphi_{2} \delta\left(s \geq t_{1}\right) e^{-\rho s} d s=A_{2}
$$

The second possibility is ruled out since player 2 should get more than his or her threat point at an interior optimum. The first order condition with respect to $t_{2}$ gives

$$
\left(\int_{0}^{t_{1}} K_{1} e^{-\rho s} d s+\int_{t_{1}}^{\infty} Z(s) \varphi_{1} e^{-\rho s} d s-A_{1}\right)\left(K_{2} e^{-\rho t_{2}}-Z\left(t_{2}\right) \varphi_{2} \delta e^{-\rho t_{2}}\right)
$$

which implies that

$$
K_{2}=Z\left(t_{2}\right) \varphi_{2} \delta
$$

or

$$
\int_{0}^{t_{1}} K_{1} e^{-\rho s} d s+\int_{t_{1}}^{\infty} Z(s) \varphi_{1} e^{-\rho s} d s=A_{1}
$$

and again the second possibility is ruled out. This implies that

$$
\begin{aligned}
& T_{1}=Z^{-1}\left(K_{1} / \varphi_{1}\right) \\
& T_{2}=Z^{-1}\left(K_{2} /\left(\varphi_{2} \delta\right)\right)
\end{aligned}
$$

which is the same outcome we obtain in Honoré and de Paula (2010). A similar set of calculations is obtained for $T_{2}<T_{1}$.

A third possibility is for spouses to retire jointly. In this case,

$$
\begin{aligned}
T= & \arg \max _{t} N(t, t) \\
= & \arg \max _{t}\left(K_{1} \rho^{-1}\left(1-e^{-\rho t}\right)+\varphi_{1} \widetilde{Z}(t)+\varphi_{1}(\delta-1) \widetilde{Z}(t)-A_{1}\right) \\
& \left(K_{2} \rho^{-1}\left(1-e^{-\rho t}\right)+\varphi_{2} \widetilde{Z}(t)+\varphi_{2}(\delta-1) \widetilde{Z}(t)-A_{2}\right) \\
= & \arg \max _{t}\left(K_{1} \rho^{-1}\left(1-e^{-\rho t}\right)+\varphi_{1} \delta \widetilde{Z}(t)-A_{1}\right)\left(K_{2} \rho^{-1}\left(1-e^{-\rho t}\right)+\varphi_{2} \delta \widetilde{Z}(t)-A_{2}\right) .
\end{aligned}
$$

The derivative of this is

$$
\begin{aligned}
& e^{-\rho t}\left(K_{1}-\varphi_{1} \delta Z(t)\right)\left(K_{2} \rho^{-1}\left(1-e^{-\rho t}\right)+\varphi_{2} \delta \widetilde{Z}(t)-A_{2}\right) \\
& +e^{-\rho t}\left(K_{1} \rho^{-1}\left(1-e^{-\rho t}\right)+\varphi_{1} \delta \widetilde{Z}(t)-A_{1}\right)\left(K_{2}-\varphi_{2} \delta Z(t)\right)
\end{aligned}
$$


which, set to zero, delivers the optimum implicitly. It can be noted that when $t<Z^{-1}\left(K_{1} /\left(\varphi_{1} \delta\right)\right)$ and $t<Z^{-1}\left(K_{2} /\left(\varphi_{2} \delta\right)\right)$ this is positive, and when $t>Z^{-1}\left(K_{1} /\left(\varphi_{1} \delta\right)\right)$ and $t>Z^{-1}\left(K_{2} /\left(\varphi_{2} \delta\right)\right)$ it is negative. The optimum is therefore in the interval

$$
\min \left\{Z^{-1}\left(K_{1} /\left(\varphi_{1} \delta\right)\right), Z^{-1}\left(K_{2} /\left(\varphi_{2} \delta\right)\right)\right\} \leq t \leq \max \left\{Z^{-1}\left(K_{1} /\left(\varphi_{1} \delta\right)\right), Z^{-1}\left(K_{2} /\left(\varphi_{2} \delta\right)\right)\right\}
$$

This is useful in the numerical solution to the above equation used in the estimation.

In any case, it should be pointed out that the set of $\left(K_{1}, K_{2}\right)$ realizations for which $T=T_{1}=T_{2}$ is an optimum is larger than the set obtained in the non-cooperative setup from Honoré and de Paula (2010). This is illustrated in Figure 2, where the area between the dotted lines is the joint retirement region in Honoré and de Paula (2010) and the area between solid lines is the joint retirement region in the current paper. Also, whereas in that paper any date within a range $\left.\max \left\{Z^{-1}\left(K_{1} /\left(\varphi_{1} \delta\right)\right), Z^{-1}\left(K_{2} /\left(\varphi_{2} \delta\right)\right)\right\}=\underline{T}<\bar{T}\right]$ was sustained as an equilibrium for pairs $\left(K_{1}, K_{2}\right)$ inducing joint retirement, in the current article the equilibrium joint retirement date for a given realization of $\left(K_{1}, K_{2}\right)$ is uniquely pinned down. Because Nash bargaining implies Pareto efficiency and because $\underline{T}$ is the Pareto dominant outcome among the possible multiple equilibria in the game analyzed by Honoré and de Paula (2010), it should be the case that joint retirement in the Nash bargaining model occurs on or before $\underline{T}$. In comparison to the non-cooperative paradigm adopted in our previous paper, Nash bargaining allows spouses to "negotiate" an earlier retirement date, which is advantageous to both.

\subsection{Estimation: Indirect Inference}

To estimate our model we employ an indirect inference strategy (see Gourieroux, Monfort, and Renault (1993); Smith (1993); and Gallant and Tauchen (1996)). Rather than estimating the Maximum Likelihood Estimator for the true model characterized by parameter $\theta$, one estimates an approximate (auxiliary) model with parameter $\beta$. Then, under the usual regularity conditions,

$$
\widehat{\beta}=\arg \max _{b} \sum_{i=1}^{n} \log \mathcal{L}_{a}\left(b ; z_{i}\right) \stackrel{p}{\longrightarrow} \arg \max _{b} E_{\theta_{0}}\left[\log \mathcal{L}_{a}\left(b ; z_{i}\right)\right] \equiv \beta_{0}\left(\theta_{0}\right)
$$


where $\mathcal{L}_{a}$ is the likelihood function for the auxiliary model and the expectation $E_{\theta_{0}}$ is taken with respect to the true model. $\beta_{0}\left(\theta_{0}\right)$ is known as the pseudo-true value and the key is that it depends on the true parameters of the data-generation process $\left(\theta_{0}\right)$. If one knew the pseudo-true value as a function of $\theta_{0}$, then it could be used to solve the equation

$$
\widehat{\beta}=\beta_{0}(\widehat{\theta})
$$

and obtain an estimator for $\theta_{0}$. In our case, we do not know $\beta_{0}(\theta)$, but we can easily approximate this function using simulations. For each $\theta$, we generate $R$ draws

$$
\left\{\left(z_{1 r}(\theta), z_{2 r}(\theta), \ldots, z_{n r}(\theta)\right)\right\}_{r=1}^{R}
$$

and then estimate the function

$$
\beta_{0}(\theta) \equiv \arg \max _{b} E_{\theta}\left[\log \mathcal{L}_{a}\left(b ; z_{i}\right)\right]
$$

by

$$
\widetilde{\beta}_{R}(\theta)=\arg \max _{b} \frac{1}{R} \sum_{r=1}^{R} \frac{1}{n} \sum_{i=1}^{n}\left(\log \mathcal{L}_{a}\left(b ; z_{i r}(\theta)\right)\right)
$$

In other words, we find $\widehat{\theta}$ such that the generated data set using $\widehat{\theta}$ gives the same estimate in the auxiliary model as we got in the real sample:

$$
\widehat{\beta}=\widetilde{\beta}_{R}(\widehat{\theta})
$$

Alternatively, one could also measure the distance between $\widehat{\beta}$ and $\widetilde{\beta}_{R}(\theta)$ by

$$
\sum_{i=1}^{n} \log \mathcal{L}_{a}\left(\widehat{\beta} ; z_{i}\right)-\sum_{i=1}^{n} \log \mathcal{L}_{a}\left(\widetilde{\beta}_{R}(\theta) ; z_{i}\right) \geq 0
$$

One could then minimize this function to make the difference between $\widehat{\beta}$ and $\widetilde{\beta}_{R}(\theta)$ as small as possible. This implies that

$$
\widehat{\beta}=\arg \max _{b} \sum_{i=1}^{n} \log \mathcal{L}_{a}\left(b ; z_{i}\right) \quad \Longrightarrow \quad \frac{1}{n} \sum_{i=1}^{n} \mathcal{S}_{a}\left(\widehat{\beta} ; z_{i}\right)=0
$$

so $\widehat{\beta}$ converges to the solution to

$$
E_{\theta}\left[\mathcal{S}_{a}\left(b ; z_{i}\right)\right]=0
$$


which is just $\beta_{0}\left(\theta_{0}\right)$ from before. So if we knew the function $\beta_{0}(\theta)$ we would estimate $\theta_{0}$ by solving $\widehat{\beta}=\beta_{0}(\widehat{\theta})$ which is the same as

$$
E_{\widehat{\theta}}\left[\mathcal{S}_{a}\left(\widehat{\beta} ; z_{i}\right)\right]=0
$$

As before, we estimate $E_{\theta}\left[\mathcal{S}_{a}\left(\cdot ; z_{i}\right)\right]$ as a function of $\theta$ using

$$
\frac{1}{R} \sum_{r=1}^{R} \frac{1}{n} \sum_{i=1}^{n} \mathcal{S}_{a}\left(\cdot ; z_{i r}(\theta)\right)
$$

and $\theta_{0}$ is estimated by solving

$$
\frac{1}{R} \sum_{r=1}^{R} \frac{1}{n} \sum_{i=1}^{n} \mathcal{S}_{a}\left(\widehat{\beta} ; z_{i r}(\theta)\right)=0 .
$$

If $\operatorname{dim}\left(\mathcal{S}_{a}\right)>\operatorname{dim}(\beta)$, we minimize

$$
\left(\frac{1}{R} \sum_{r=1}^{R} \frac{1}{n} \sum_{i=1}^{n} \mathcal{S}_{a}\left(\widehat{\beta} ; z_{i r}(\theta)\right)\right)^{\top} W\left(\frac{1}{R} \sum_{r=1}^{R} \frac{1}{n} \sum_{i=1}^{n} \mathcal{S}_{a}\left(\widehat{\beta} ; z_{i r}(\theta)\right)\right)
$$

over $\theta$. The weighting matrix $W$ is a positive definite matrix performing the usual role in terms of estimator efficiency. This strategy is useful because we only estimate the auxiliary model once using the real data. After that, we evaluate its FOC for different draws of $\theta$.

\subsubsection{Auxiliary Model}

Our auxiliary model is composed of three reduced form models that are chosen to capture the features of the data that are our main concern: the duration until retirement for each spouse, and the idea that members of some married couples choose to retire jointly. For the first two, we use a standard proportional hazard model for each spouse with a Weibull baseline hazard and the usual specification for the covariate function. For the third, we use an ordered Logit model as suggested by our paper Honoré and de Paula (2010). We present the models in detail below.

\section{Weibull Proportional Hazard Model}

For each spouse, the baseline hazard for retirement is assumed to be

$$
Z(t)=t^{\alpha} \Rightarrow \lambda(t) \equiv Z^{\prime}(t)=\alpha t^{\alpha-1}
$$


and the covariate function is $\varphi(x)=\exp \left(x^{\top} \beta\right)$. The $(\log )$ density of retirement conditional on $x$ is then given by:

$\log f(t \mid x)=\log \left\{\lambda(t) \exp \left(x^{\top} \beta\right) \exp \left(-Z(t) \exp \left(x^{\top} \beta\right)\right)\right\}=\log \alpha+(\alpha-1) \log t+x^{\top} \beta-t^{\alpha} \exp \left(x^{\top} \beta\right)$

The (conditional) survivor function can be analogously obtained and is given by:

$$
\log S(t \mid x)=\log \left\{\exp \left(-Z(t) \exp \left(x^{\top} \beta\right)\right)\right\}=-t^{\alpha} \exp \left(x^{\top} \beta\right)
$$

Letting $c_{i}=1$ if the observation is (right-)censored, and $=0$ otherwise, we obtain the log-likelihood function:

$$
\log \mathcal{L}=\sum_{i=1}^{n}\left(1-c_{i}\right)\left(\log \alpha+(\alpha-1) \log \left(t_{i}\right)+x_{i}^{\prime} \beta\right)-\sum_{i=1}^{n} t_{i}^{\alpha} \exp \left(x_{i}^{\prime} \beta\right)
$$

First and second derivatives used in the computation of the MLE for this auxiliary model are presented in the Appendix.

\section{Ordered Logit Model Pseudo MLE}

In the spirit of the estimation strategy suggested in Honoré and de Paula (2010), we also use as auxiliary model an ordered logit. Whereas the Weibull model will convey information on the timing of retirement, this second auxiliary model will provide information on the pervasiveness of joint retirement and help identify the taste interactions leading to this phenomenon (i.e. $\delta$ ). Define

$$
y_{i}= \begin{cases}1, & \text { if } t_{1}>t_{2} \\ 2, & \text { if } t_{1}=t_{2} \\ 3, & \text { if } t_{1}<t_{2}\end{cases}
$$

The model is then given by:

$$
y_{i}^{\star}=x_{i}^{\top} \beta-\varepsilon_{i}, \quad y_{i}=\left\{\begin{array}{ccc}
0 & \text { if } & y_{i}^{\star}<0 \\
1 & \text { if } & 0 \leq y_{i}^{\star}<\alpha \\
2 & \text { if } & \alpha \leq y_{i}^{\star}
\end{array}\right.
$$

where we also include an intercept. Then

$$
P\left(y_{i}=1 \text { or } y_{i}=2\right)=\Lambda\left(x_{i}^{\top} \beta\right)
$$




$$
P\left(y_{i}=2\right)=\Lambda\left(x_{i}^{\top} \beta-\alpha\right)
$$

which allows us to construct the following pseudo-likelihood function:

$$
\mathcal{Q}=\sum_{y_{i}=0} \log \left(1-\Lambda\left(x_{0 i}^{\top} \theta\right)\right)+\sum_{y_{i} \neq 0} \log \left(\Lambda\left(x_{0 i}^{\top} \theta\right)\right)+\sum_{y_{i} \neq 2} \log \left(1-\Lambda\left(x_{1 i}^{\top} \theta\right)\right)+\sum_{y_{i}=2} \log \left(\Lambda\left(x_{1 i}^{\top} \theta\right)\right)
$$

where

$$
x_{0 i}=\left(x_{i}^{\top}: \mathbf{0}\right)^{\top} \quad x_{1 i}=\left(x_{i}^{\top} \vdots \mathbf{1}\right)^{\top} \quad \theta=\left(\beta^{\top}:-\alpha\right)^{\top}
$$

As before, first and second order derivatives are presented in the Appendix.

\section{Overall Auxiliary Model}

Our final auxiliary model objective function is then defined by the pseudo-loglikelihood function

$$
\log \mathcal{L}_{\text {men }}\left(\beta_{1}\right)+\log \mathcal{L}_{\text {women }}\left(\beta_{2}\right)+\mathcal{Q}\left(\beta_{3}\right)
$$

and the moment conditions used for estimating the parameters of the structural model are the first order conditions for maximizing this.

As is customary, we choose as our weighting matrix $W=\widehat{J}_{0}^{-1}$, where

$$
\widehat{J_{0}}=\widehat{V}\left[\left(\begin{array}{c}
\frac{\partial \log \mathcal{L}_{m i}}{\partial \beta_{1}} \\
\frac{\partial \log \mathcal{L}_{w i}}{\partial \beta_{2}} \\
\frac{\partial \mathcal{Q}_{i}}{\partial \beta_{3}}
\end{array}\right)\right]
$$

The (asymptotic) standard errors of the structural estimates are calculated using the formulae in Gourieroux and Monfort (1996).

\section{Data}

In the United States, full retirement age for those reaching 62 before 2000 was 65 years old. The full retirement age has been increasing ever since until it reaches 67 for those reaching 62 in 2022. Workers who claim early retirement (between ages 62 to 65) have their basic benefit (PIA, primary insurance account) reduced proportionately. Individuals who delay retirement receive increases in benefits for every month of delayed retirement before age 70 . (The rate of 
increase rose gradually until reaching 8 percent for year of delayed retirement in 2005.) Those claiming early retirement are also subject to an earnings test whereby half of the earnings above a certain threshold are withheld. Most of the lost earnings are treated as delayed receipt. (Until 2000, recipients were also subject to an earnings test during the first five years of retirement.) Aside from the OASDI (Old Age, Survivors, and Disability Insurance) program, the SSA also administers the SSI (Supplemental Security Income) program, which provides assistance to individuals age 65 or older as well as disabled. The entitlement level is unrelated to previous work earnings and is based on the individual or couple's income and net worth.

We estimate the model using eight waves of the Health and Retirement Study and keep households where at least one individual was 60 years-old or more. We classify as retired a respondent who is not working, and not looking for work and if there is any mention of retirement through the employment status or the questions that ask the respondent whether he or she considers him or herself retired 4 To avoid left-censoring, selected households also had both partners working at the initial period. We excluded individuals who were part of the military. This leaves us with 1,469 couples.

We condition covariates on the first "household year": when the oldest partner reaches 60 years-old. The covariates we use are:

1. the age difference in the couple (husband's age - wife's age in years);

2. dummies for race (non-Hispanic black, Hispanic and other race with non-Hispanic whites as the omitted category);

3. dummies for education (high school or GED, some college and college or above with less than high school as the omitted category);

4. indicators of region (NE, SO, and WE with MW or other region as omitted category);

5. self-reported health dummies (good health, very good health, with poor health as the omitted category);

\footnotetext{
${ }^{4}$ Specifically we use the classification provided by the variable RwLBRF.
} 
6. an indicator for whether the person has health insurance;

7. the total health expenditure (in dollars);

8. indicators for whether the person had a defined contribution (DC) or defined benefit (DB) plan; and

9. financial wealth 5

Table 1 presents the Kaplan-Meier estimates for the retirement behavior in our sample (measured in year of retirement):

\section{Results}

We now present our estimation results using monthly data on retirement in couples. The discount rate $\rho$ is set to 0.04 and the threat points are set at the utility level they would have obtained if his or her partner never retired ${ }^{6}$ The number of simulations in each set of estimates is $R=5$. We assume that $Z(t)=t^{\alpha}$ implying a Weibull baseline hazard for a model with $\delta=1$. Utility flows while in the labor force are drawn from independent unit exponentials $\left(K_{i} \sim \exp (1)\right)$.

Tables 2 and 3 present results for wives and husbands when $\delta$ is restricted to 1 . Results are very robust across covariate specifications. There is positive duration dependence: retirement is more likely as the household ages. Age differences tend to increase the retirement hazard for women and decrease it for men. Since men are typically older and we count "family age" from the 60th year of the oldest partner, a larger age difference implies that the wife is younger at time zero and less likely to retire at any "family age" than an older woman (i.e., a wife in a household with a lower age difference). Both non-white men and women have lower retirement hazard than non-Hispanic whites, though only Hispanics' coefficients tend to be significant.

\footnotetext{
${ }^{5}$ For financial wealth we use the transformation $\operatorname{sgn}($ financial wealth $) \times \sqrt{\text { financial wealth }}$.

${ }^{6}$ In our estimations, we experimented with multiples of this scaled by 0 and 0.6 as well. Results are not much different and hence omitted.
} 
More educated women, but especially those with high school or GED and in some covariate specifications with college, seem to retire earlier than those without high school, but the coefficients on those categories are not statistically significant. For men, collegeeducated husbands retire later than all other categories and the association is statistically significant. There is some evidence that high school graduates retire earlier but the effect is numerically small and statistically insignificant. There is some evidence that husbands in the Northeast retire earlier whereas those in the South and West retire later than those in the Midwest. The only statistically significant coefficients are those associated with the South though. Geographical region does not seem to play a statistically significant role for women. Furthermore, depending on the covariate specification, Northeast and Southern women have a lower or higher hazard than those in the Midwest. Western wives do seem to retire earlier in all covariate specifications, but then again standard errors are quite imprecise.

Self-reported health lowers the hazard with healthier people retiring later than those in poor health. Only the female coefficient on "good health" is significant nonetheless. Having health insurance increases the hazard for both husbands and wives, though not in a statistically significant way. Total health expenditures increase the hazard as well. Having a defined benefit contribution pension plan increases the probability of retirement for both genders in a numerically and statistically significant manner. A defined contribution plan affects negatively and significantly the male hazard of men but not the female. Wealthier women tend to retire later, but financial wealth does not affect the hazard of men significantly.

Once joint retirement is accounted for, ( 1 ) the precision of the Hispanic coefficient decreases substantially, especially for women and particularly in our last covariate specification, though the numerical estimates also increase; ( 2 ) the coefficient estimate on "good health" decreases numerically and is more imprecisely estimated as well, ceasing to be statistically significant for wives; and ( 3 ) having a defined contribution plan is not statistically significant for husbands' retirement hazards any longer. 


\section{Concluding Remarks}

We have presented a novel model that nests the usual proportional hazards models, but which both accounts for joint termination of spells and is built upon an economic model of joint decision making. We applied the model to retirement of husband and wife. Once joint retirement is accounted for, a few features are no longer significant.

\section{Appendix}

\section{Log-likelihood Derivatives: Weibull Model}

$$
\begin{gathered}
\frac{\partial \log \mathcal{L}}{\partial \alpha}=\sum_{i=1}^{n}\left(1-c_{i}\right)\left(\frac{1}{\alpha}+\log \left(t_{i}\right)\right)-\sum_{i=1}^{n} t_{i}^{\alpha} \log \left(t_{i}\right) \exp \left(x_{i}^{\prime} \beta\right) \\
\frac{\partial \log \mathcal{L}}{\partial \beta}=\sum_{i=1}^{n}\left(1-c_{i}\right) x_{i}-\sum_{i=1}^{n} t_{i}^{\alpha} \exp \left(x_{i}^{\prime} \beta\right) x_{i} \\
\frac{\partial^{2} \log \mathcal{L}}{\partial \alpha^{2}}=-\sum_{i=1}^{n}\left(1-c_{i}\right) \frac{1}{\alpha^{2}}-\sum_{i=1}^{n} t_{i}^{\alpha} \log \left(t_{i}\right)^{2} \exp \left(x_{i}^{\prime} \beta\right) \\
\frac{\partial^{2} \log \mathcal{L}}{\partial \alpha \partial \beta^{\prime}}=-\sum_{i=1}^{n} t_{i}^{\alpha} \log \left(t_{i}\right) \exp \left(x_{i}^{\prime} \beta\right) x_{i} \\
\frac{\partial^{2} \log \mathcal{L}}{\partial \beta \partial \beta^{\prime}}=-\sum_{i=1}^{n} t_{i}^{\alpha} \exp \left(x_{i}^{\prime} \beta\right) x_{i} x_{i}^{\prime}
\end{gathered}
$$

To impose $\alpha>0$ in our computations we parameterize $\alpha=\exp (\theta)$. Then,

$$
\begin{gathered}
\frac{\partial \log \mathcal{L}}{\partial \theta}=\frac{\partial \log \mathcal{L}}{\partial \alpha} \frac{\partial \alpha}{\partial \theta}=\left(\sum_{i=1}^{n}\left(1-c_{i}\right)\left(\frac{1}{\alpha}+\log \left(t_{i}\right)\right)-\sum_{i=1}^{n} t_{i}^{\alpha} \log \left(t_{i}\right) \exp \left(x_{i}^{\prime} \beta\right)\right) \alpha \\
\frac{\partial \log \mathcal{L}}{\partial \beta}=\sum_{i=1}^{n}\left(1-c_{i}\right) x_{i}-\sum_{i=1}^{n} t_{i}^{\alpha} \exp \left(x_{i}^{\prime} \beta\right) x_{i}
\end{gathered}
$$




$$
\begin{aligned}
\frac{\partial^{2} \log \mathcal{L}}{\partial \theta^{2}}= & \frac{\partial}{\partial \theta}\left(\frac{\partial \log \mathcal{L}}{\partial \alpha} \frac{\partial \alpha}{\partial \theta}\right) \\
= & \frac{\partial^{2} \log \mathcal{L}}{\partial \alpha^{2}}\left(\frac{\partial \alpha}{\partial \theta}\right)^{2}+\frac{\partial \log \mathcal{L}}{\partial \alpha} \frac{\partial^{2} \alpha}{\partial \theta^{2}} \\
= & \left(-\sum_{i=1}^{n}\left(1-c_{i}\right) \frac{1}{\alpha^{2}}-\sum_{i=1}^{n} t_{i}^{\alpha} \log \left(t_{i}\right)^{2} \exp \left(x_{i}^{\prime} \beta\right)\right) \alpha^{2} \\
& -\left(\sum_{i=1}^{n}\left(1-c_{i}\right)\left(\frac{1}{\alpha}+\log \left(t_{i}\right)\right)-\sum_{i=1}^{n} t_{i}^{\alpha} \log \left(t_{i}\right) \exp \left(x_{i}^{\prime} \beta\right)\right) \alpha \\
\frac{\partial^{2} \log \mathcal{L}}{\partial \theta \partial \beta^{\prime}}= & \frac{\partial^{2} \log \mathcal{L}}{\partial \alpha \partial \beta^{\prime}} \frac{\partial \alpha}{\partial \theta}=\left(-\sum_{i=1}^{n} t_{i}^{\alpha} \log \left(t_{i}\right) \exp \left(x_{i}^{\prime} \beta\right) x_{i}\right) \alpha \\
\frac{\partial^{2} \log \mathcal{L}}{\partial \beta \partial \beta^{\prime}}= & -\sum_{i=1}^{n} t_{i}^{\alpha} \exp \left(x_{i}^{\prime} \beta\right) x_{i} x_{i}^{\prime}
\end{aligned}
$$

\section{Pseudo-likelihood Derivatives: Ordered Model}

$$
\begin{gathered}
\frac{\partial \mathcal{Q}}{\partial \theta}=\sum_{i}\left[\left(1\left\{y_{i} \neq 0\right\}-\Lambda\left(x_{0 i}^{\top} \theta\right)\right) x_{0 i}+\left(1\left\{y_{i}=2\right\}-\Lambda\left(x_{1 i}^{\top} \theta\right)\right) x_{1 i}\right] \\
\frac{\partial^{2} \mathcal{Q}}{\partial \theta \partial \theta^{\top}}=-\sum_{i}\left[\left(\left(1-\Lambda\left(x_{0 i}^{\top} \theta\right)\right) \Lambda\left(x_{0 i}^{\top} \theta\right)\right) x_{0 i} x_{0 i}^{\top}+\left(\left(1-\Lambda\left(x_{1 i}^{\top} \theta\right)\right) \Lambda\left(x_{1 i}^{\top} \theta\right)\right) x_{1 i} x_{1 i}^{\top}\right]
\end{gathered}
$$




\section{References}

An, M., B. Christensen, And N. Gupta (2004): "Multivariate Mixed Proportional Hazard Modeling of the Joint Retirement of Married Couples," Journal of Applied Econometrics, 19(6), 687-704.

Banks, J., R. Blundell, and M. Casanova Rivas (2007): "The Dynamics of Retirement Behavior in Couples: Reduced-Form Evidence from England and the U.S.," Working Paper, University College London (UCL).

Blau, D. (1998): "Labor Force Dynamics of Older Married Couples," Journal of Labor Economics, 16(3), 595-629.

Blau, D., And D. Gilleskie (2004): "Health Insurance and Retirement of Married Couples," Working Paper, University of North Carolina at Chapel Hill.

Browning, M., P.-A. Chiappori, And V. Lechene (2006): "Collective and Unitary Models: A Clarification," Review of Economics of the Household, 4(1), 5-14.

Burtless, G. (1990): "Comment on M. Hurd's 'The Joint Retirement Decisions of Husbands and Wives'," in Issues in the Economics of Aging, ed. by D. A. Wise. Chicago: University of Chicago Press.

Casanova Rivas, M. (2010): "Happy Together: A Structural Model of Couples' Joint Retirement Choices," Working Paper, University of California at Los Angeles (UCLA).

Chiappori, P.-A. (1992): "Collective Labor Supply and Welfare," Journal of Political Economy.

Chiappori, P.-A., O. Donni, And I. Komunjer (2010): "Learning from a Piece of Pie," Columbia University Working Paper.

CoIle, C. (2004a): "Health Shocks and Couples' Labor Supply Decisions," (10810), NBER Working paper. 
- (2004b): "Retirement Incentives and Couples' Retirement Decisions," Topics in Economic Analysis and Policy, 4(1).

DE Paula, A. (2009): "Inference in a Synchronization Game with Social Interactions," Journal of Econometrics, 148(1), 56-71.

Gallant, R., and G. Tauchen (1996): "Which moments to match?," Econometric Theory, $12(4)$.

Gourieroux, C., And A. Monfort (1996): Simulation-Based Econometric Methods. Oxford: Oxford University Press.

Gourieroux, C., A. Monfort, and E. Renault (1993): "Indirect Inference," Journal of Applied Econometrics, 8, S85-S118.

Gustman, A., And T. Steinmeier (2000): "Retirement in Dual-Career Families: A Structural Model," Journal of Labor Economics, 18(3), 503-545.

- (2004): "Social Security, Pensions and Retirement Behaviour with the Family," Journal of Applied Econometrics, 19, 723-737.

_ (2009): "Integrating Retirement Models," NBER Working Paper 15607.

Honoré, B., And A. DE Paula (2010): "Interdependent Durations," Review of Economic Studies, 77, 11381163.

Hurd, M. (1990): "The Joint Retirement Decisions of Husbands and Wives," in Issues in the Economics of Aging, ed. by D. A. Wise. Chicago: University of Chicago Press.

Magnac, T., J.-M. Robin, And M. Visser (1995): "Analysing Incomplete Individual Employment Histories Using Indirect Inference," jae, 10, S153-S169.

Manski, C. (1993): "Identification of Endogenous Social Effects: The Reflection Problem," res, 60(3), 531-542. 
Michaud, P., And F. Vermeulen (forthcoming): "A Collective Labor Supply Model with Complementarities in Leisure: Identification and Estimation by Means of Panel Data," Labour Economics.

Michaud, P.-C. (2003): "Labor Force Participation Dynamics and Social Security Claiming Decisions of Elderly Couples," Working Paper, CentER Tilburn University and IZA.

NASH, J. (1950): "The Bargaining Problem," Econometrica, 18, 155162.

Sмiтh, A. (1993): "Estimating nonlinear time series models using vector-autoregressions: Two approaches," Journal of Applied Econometrics, 8, S63-S84.

Zeuthen, F. (1930): Problems of Monopoly and Economic Warfare. London: Routledge. 


\section{Appendix: Figures and Tables}

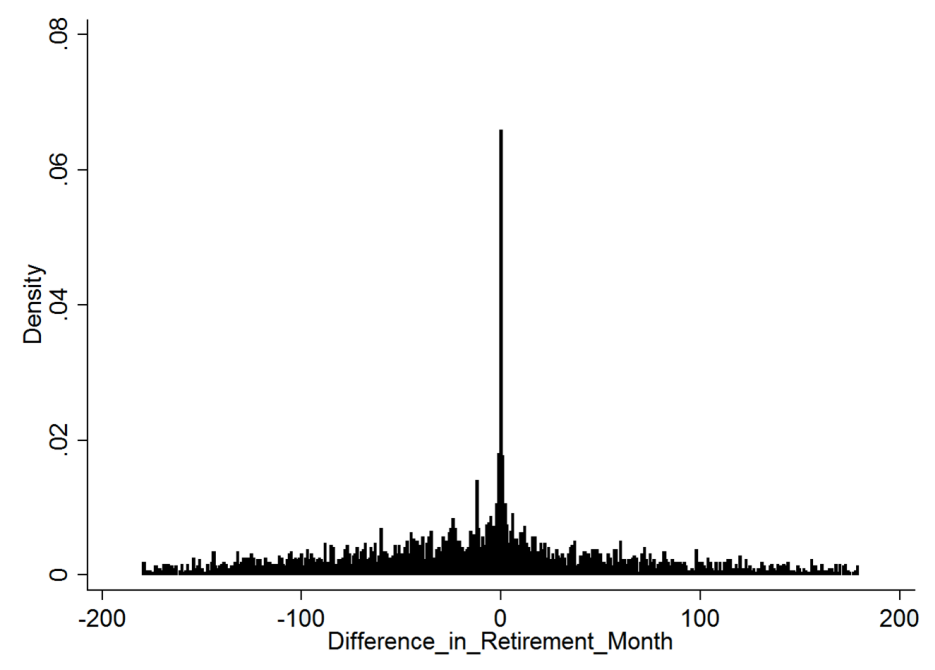

Figure 1: Difference in Retirement Months (Husband-Wife)

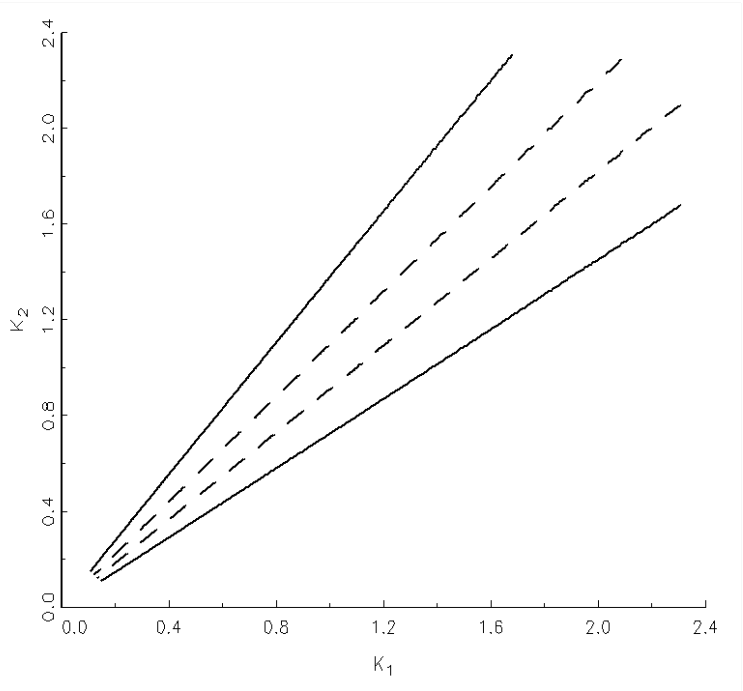

Figure 2: Joint Retirement Regions 
Table 1: Kaplan-Meier Estimates

\begin{tabular}{l|ccccc|ccccc}
\hline \hline $\begin{array}{l}\text { Time } \\
(\text { Yrs. })\end{array}$ & $\begin{array}{c}\text { Beg. } \\
\text { Total }\end{array}$ & Fail & $\begin{array}{c}\text { Net } \\
\text { Lost }\end{array}$ & $\begin{array}{c}\text { Survivor } \\
\text { Function }\end{array}$ & $\begin{array}{c}\text { Std. } \\
\text { Error }\end{array}$ & $\begin{array}{c}\text { Beg. } \\
\text { Total }\end{array}$ & $\begin{array}{c}\text { Fail } \\
\text { Lost }\end{array}$ & $\begin{array}{c}\text { Survivor } \\
\text { Function }\end{array}$ & $\begin{array}{c}\text { Std. } \\
\text { Error }\end{array}$ \\
\hline & \multicolumn{7}{|c}{ Husbands } \\
\hline 1 & 1385 & 108 & 174 & 0.922 & 0.007 & 944 & 100 & 103 & 0.894 & 0.010 \\
2 & 1103 & 76 & 232 & 0.859 & 0.010 & 741 & 83 & 130 & 0.794 & 0.014 \\
3 & 795 & 72 & 96 & 0.781 & 0.012 & 528 & 81 & 52 & 0.672 & 0.017 \\
4 & 627 & 78 & 76 & 0.684 & 0.015 & 395 & 50 & 49 & 0.587 & 0.019 \\
5 & 473 & 69 & 98 & 0.584 & 0.017 & 296 & 61 & 39 & 0.466 & 0.020 \\
6 & 306 & 66 & 35 & 0.458 & 0.019 & 196 & 45 & 11 & 0.359 & 0.021 \\
7 & 205 & 48 & 22 & 0.351 & 0.020 & 140 & 28 & 13 & 0.287 & 0.021 \\
8 & 135 & 37 & 9 & 0.255 & 0.020 & 99 & 29 & 8 & 0.203 & 0.020 \\
9 & 89 & 17 & 11 & 0.206 & 0.019 & 62 & 21 & 4 & 0.134 & 0.018 \\
10 & 61 & 19 & 6 & 0.142 & 0.018 & 37 & 16 & 1 & 0.076 & 0.015 \\
11 & 36 & 17 & 2 & 0.075 & 0.015 & 20 & 8 & 0 & 0.046 & 0.012 \\
12 & 17 & 8 & 2 & 0.040 & 0.012 & 12 & 9 & 0 & 0.011 & 0.007 \\
13 & 7 & 7 & 0 & 0.000 &. & 3 & 3 & 0 & 0.000 &. \\
\hline \hline
\end{tabular}


Table 2: WIVES' Proportional Hazards (Weibull Baseline)

\begin{tabular}{|c|c|c|c|c|c|c|}
\hline Variable & $\begin{array}{c}\text { Coef. } \\
\text { (Std. Err.) }\end{array}$ & $\begin{array}{c}\text { Coef. } \\
\text { (Std. Err.) }\end{array}$ & $\begin{array}{c}\text { Coef. } \\
\text { (Std. Err.) }\end{array}$ & $\begin{array}{c}\text { Coef. } \\
\text { (Std. Err.) }\end{array}$ & $\begin{array}{c}\text { Coef. } \\
\text { (Std. Err.) }\end{array}$ & $\begin{array}{c}\text { Coef. } \\
\text { (Std. Err.) }\end{array}$ \\
\hline$\alpha$ & $\begin{array}{l}1.227 \\
(0.042)\end{array}$ & $\begin{array}{l}1.234 \\
(0.043)\end{array}$ & $\begin{array}{l}1.237 \\
(0.043)\end{array}$ & $\begin{array}{l}1.239 \\
(0.044)\end{array}$ & $\begin{array}{l}1.245 \\
(0.045)\end{array}$ & $\begin{array}{l}1.247 \\
(0.045)\end{array}$ \\
\hline Constant & $\begin{array}{c}-5.840^{* *} \\
(0.185)\end{array}$ & $\begin{array}{c}-5.978^{* *} \\
(0.238)\end{array}$ & $\begin{array}{c}-5.792^{* *} \\
(0.270)\end{array}$ & $\begin{array}{c}-6.012^{* *} \\
(0.330)\end{array}$ & $\begin{array}{c}-5.954^{* *} \\
(0.328)\end{array}$ & $\begin{array}{c}-5.999^{* *} \\
(0.329)\end{array}$ \\
\hline Age Diff. & $\begin{array}{c}-0.068^{* *} \\
(0.010)\end{array}$ & $\begin{array}{c}-0.068 \text { ** } \\
(0.011)\end{array}$ & $\begin{array}{c}-0.067^{* *} \\
(0.011)\end{array}$ & $\begin{array}{c}-0.070 * * \\
(0.011)\end{array}$ & $\begin{array}{c}-0.070 \text { ** } \\
(0.011)\end{array}$ & $\begin{array}{c}-0.070 \text { ** } \\
(0.011)\end{array}$ \\
\hline Nonhisp. Black & & $\begin{array}{c}-0.134 \\
(0.165)\end{array}$ & $\begin{array}{l}-0.122 \\
(0.168)\end{array}$ & $\begin{array}{l}-0.051 \\
(0.174)\end{array}$ & $\begin{array}{l}-0.076 \\
(0.173)\end{array}$ & $\begin{array}{l}-0.039 \\
(0.175)\end{array}$ \\
\hline Other race & & $\begin{array}{l}-0.440 \\
(0.286)\end{array}$ & $\begin{array}{l}-0.451 \\
(0.288)\end{array}$ & $\begin{array}{c}-0.337 \\
(0.290)\end{array}$ & $\begin{array}{c}-0.320 \\
(0.292)\end{array}$ & $\begin{array}{l}-0.287 \\
(0.294)\end{array}$ \\
\hline Hispanic & & $\begin{array}{c}-0.472 * \\
(0.189)\end{array}$ & $\begin{array}{c}-0.521^{* *} \\
(0.197)\end{array}$ & $\begin{array}{c}-0.412 * \\
(0.205)\end{array}$ & $\begin{array}{c}-0.453^{*} \\
(0.204)\end{array}$ & $\begin{array}{c}-0.4166^{*} \\
(0.206)\end{array}$ \\
\hline High school or GED & & $\begin{array}{c}0.188 \\
(0.150)\end{array}$ & $\begin{array}{c}0.212 \\
(0.152)\end{array}$ & $\begin{array}{l}0.224 \\
(0.158)\end{array}$ & $\begin{array}{c}0.188 \\
(0.160)\end{array}$ & $\begin{array}{c}0.167 \\
(0.160)\end{array}$ \\
\hline Some college & & $\begin{array}{c}0.087 \\
(0.160)\end{array}$ & $\begin{array}{c}0.097 \\
(0.163)\end{array}$ & $\begin{array}{c}0.093 \\
(0.170)\end{array}$ & $\begin{array}{c}0.061 \\
(0.171)\end{array}$ & $\begin{array}{l}0.004 \\
(0.174)\end{array}$ \\
\hline College or above & & $\begin{array}{c}0.228 \\
(0.173)\end{array}$ & $\begin{array}{c}0.242 \\
(0.176)\end{array}$ & $\begin{array}{c}0.263 \\
(0.184)\end{array}$ & $\begin{array}{c}0.135 \\
(0.190)\end{array}$ & $\begin{array}{l}0.049 \\
(0.195)\end{array}$ \\
\hline NE & & $\begin{array}{c}0.008 \\
(0.146)\end{array}$ & $\begin{array}{c}0.006 \\
(0.146)\end{array}$ & $\begin{array}{c}-0.068 \\
(0.152)\end{array}$ & $\begin{array}{l}-0.107 \\
(0.153)\end{array}$ & $\begin{array}{l}-0.121 \\
(0.153)\end{array}$ \\
\hline $\mathrm{SO}$ & & $\begin{array}{c}-0.001 \\
(0.118)\end{array}$ & $\begin{array}{c}-0.004 \\
(0.119)\end{array}$ & $\begin{array}{c}0.020 \\
(0.122)\end{array}$ & $\begin{array}{l}-0.019 \\
(0.122)\end{array}$ & $\begin{array}{l}-0.019 \\
(0.122)\end{array}$ \\
\hline WE & & $\begin{array}{l}0.220 \\
(0.145)\end{array}$ & $\begin{array}{c}0.217 \\
(0.147)\end{array}$ & $\begin{array}{c}0.169 \\
(0.150)\end{array}$ & $\begin{array}{c}0.163 \\
(0.148)\end{array}$ & $\begin{array}{c}0.163 \\
(0.149)\end{array}$ \\
\hline V Good Health & & & $\begin{array}{l}-0.200 \\
(0.152)\end{array}$ & $\begin{array}{c}-0.214 \\
(0.170)\end{array}$ & $\begin{array}{l}-0.262 \\
(0.170)\end{array}$ & $\begin{array}{l}-0.254 \\
(0.172)\end{array}$ \\
\hline Good Health & & & $\begin{array}{c}-0.321^{*} \\
(0.159)\end{array}$ & $\begin{array}{c}-0.365^{*} \\
(0.174)^{2}\end{array}$ & $\begin{array}{c}-0.397^{*} \\
(0.173)\end{array}$ & $\begin{array}{c}-0.389^{*} \\
(0.175)\end{array}$ \\
\hline Health Insurance & & & & $\begin{array}{l}0.304^{\dagger} \\
(0.170)\end{array}$ & $\begin{array}{c}0.229 \\
(0.174)\end{array}$ & $\begin{array}{l}0.206 \\
(0.173)\end{array}$ \\
\hline Tot. Health Exp. & & & & $\begin{array}{c}0.000 \\
(0.001)\end{array}$ & $\begin{array}{c}0.000 \\
(0.001)\end{array}$ & $\begin{array}{l}0.000 \\
(0.001)\end{array}$ \\
\hline Pension (DC) & & & & & $\begin{array}{c}0.031 \\
(0.127)\end{array}$ & $\begin{array}{c}0.055 \\
(0.128)\end{array}$ \\
\hline Pension (DB) & & & & & $\begin{array}{l}0.361 * * \\
(0.119)\end{array}$ & $\begin{array}{l}0.377^{* *} \\
(0.119)\end{array}$ \\
\hline Fin. Wealth & & & & & & $\begin{array}{l}0.351^{*} \\
(0.179)\end{array}$ \\
\hline
\end{tabular}

1. Significance levels : $\quad \dagger: 10 \% \quad *: 5 \% \quad * *: 1 \%$. Significance levels are not displayed for $\alpha$.

2. Omitted categories are Non-Hisp. White, Less than high school Midwest or Other Region, and Poor Health. 
Table 3: HUSBANDS' Proportional Hazards (Weibull Baseline)

\begin{tabular}{|c|c|c|c|c|c|c|}
\hline Variable & $\begin{array}{c}\text { Coef. } \\
\text { (Std. Err.) }\end{array}$ & $\begin{array}{c}\text { Coef. } \\
\text { (Std. Err.) }\end{array}$ & $\begin{array}{c}\text { Coef. } \\
\text { (Std. Err.) }\end{array}$ & $\begin{array}{c}\text { Coef. } \\
\text { (Std. Err.) }\end{array}$ & $\begin{array}{c}\text { Coef. } \\
\text { (Std. Err.) }\end{array}$ & $\begin{array}{c}\text { Coef. } \\
\text { (Std. Err.) }\end{array}$ \\
\hline$\alpha$ & $\begin{array}{l}1.213 \\
(0.035)\end{array}$ & $\begin{array}{l}1.233 \\
(0.036)\end{array}$ & $\begin{array}{c}1.233 \\
(0.036)\end{array}$ & $\begin{array}{c}1.221 \\
(0.037)\end{array}$ & $\begin{array}{c}1.232 \\
(0.038)\end{array}$ & $\begin{array}{l}1.232 \\
(0.038)\end{array}$ \\
\hline Constant & $\begin{array}{c}-5.504 * * \\
(0.153)\end{array}$ & $\begin{array}{c}-5.396^{* *} \\
(0.194)\end{array}$ & $\begin{array}{c}-5.341^{* *} \\
(0.220)\end{array}$ & $\begin{array}{c}-5.654^{* *} \\
(0.263)\end{array}$ & $\begin{array}{c}-5.704^{* *} \\
(0.268)\end{array}$ & $\begin{array}{c}-5.711^{* *} \\
(0.267)\end{array}$ \\
\hline Age Diff. & $\begin{array}{l}0.020^{* *} \\
(0.006)\end{array}$ & $\begin{array}{c}0.023^{* *} \\
(0.006)\end{array}$ & $\begin{array}{l}0.023^{* *} \\
(0.006)\end{array}$ & $\begin{array}{l}0.028^{* *} \\
(0.006)\end{array}$ & $\begin{array}{c}0.027 \text { ** } \\
(0.006)\end{array}$ & $\begin{array}{l}0.027 * * \\
(0.006)\end{array}$ \\
\hline Non-Hisp. Black & & $\begin{array}{c}-0.140 \\
(0.148)\end{array}$ & $\begin{array}{l}-0.151 \\
(0.151)\end{array}$ & $\begin{array}{l}-0.075 \\
(0.153)\end{array}$ & $\begin{array}{c}-0.086 \\
(0.152)\end{array}$ & $\begin{array}{l}-0.076 \\
(0.153)\end{array}$ \\
\hline Other race & & $\begin{array}{l}-0.223 \\
(0.256)\end{array}$ & $\begin{array}{l}-0.225 \\
(0.254)\end{array}$ & $\begin{array}{l}-0.201 \\
(0.273)\end{array}$ & $\begin{array}{l}-0.182 \\
(0.274)\end{array}$ & $\begin{array}{l}-0.181 \\
(0.275)\end{array}$ \\
\hline Hispanic & & $\begin{array}{c}-0.604^{* *} \\
(0.165)\end{array}$ & $\begin{array}{c}-0.615^{* *} \\
(0.167)\end{array}$ & $\begin{array}{c}-0.456^{* *} \\
(0.170)\end{array}$ & $\begin{array}{c}-0.455^{* *} \\
(0.172)\end{array}$ & $\begin{array}{c}-0.446^{* *} \\
(0.173)\end{array}$ \\
\hline High school or GED & & $\begin{array}{c}0.047 \\
(0.120)\end{array}$ & $\begin{array}{c}0.048 \\
(0.120)\end{array}$ & $\begin{array}{c}0.046 \\
(0.124)\end{array}$ & $\begin{array}{c}0.070 \\
(0.126)\end{array}$ & $\begin{array}{c}0.066 \\
(0.127)\end{array}$ \\
\hline Some college & & $\begin{array}{c}-0.015 \\
(0.129)\end{array}$ & $\begin{array}{c}-0.013 \\
(0.129)\end{array}$ & $\begin{array}{c}-0.013 \\
(0.133)\end{array}$ & $\begin{array}{c}0.006 \\
(0.134)\end{array}$ & $\begin{array}{l}-0.005 \\
(0.136)\end{array}$ \\
\hline College or above & & $\begin{array}{c}-0.289^{*} \\
(0.126)\end{array}$ & $\begin{array}{c}-0.281^{*} \\
(0.126)\end{array}$ & $\begin{array}{c}-0.251{ }^{*} \\
(0.131)\end{array}$ & $\frac{-0.231{ }^{\dagger}}{(0.132)}$ & $\begin{array}{c}-0.250^{\dagger} \\
(0.137)\end{array}$ \\
\hline $\mathrm{NE}$ & & $\begin{array}{c}0.125 \\
(0.116)\end{array}$ & $\begin{array}{c}0.126 \\
(0.117)\end{array}$ & $\begin{array}{c}0.128 \\
(0.118)\end{array}$ & $\begin{array}{c}0.128 \\
(0.116)\end{array}$ & $\begin{array}{c}0.126 \\
(0.116)\end{array}$ \\
\hline $\mathrm{SO}$ & & $\begin{array}{c}-0.193^{\dagger} \\
(0.101)\end{array}$ & $\begin{array}{c}-0.191{ }^{\dagger} \\
(0.101)\end{array}$ & $\begin{array}{l}-0.164 \\
(0.104)\end{array}$ & $\begin{array}{l}-0.171 \\
(0.104)\end{array}$ & $\begin{array}{r}-0.172^{\dagger} \\
(0.104)\end{array}$ \\
\hline WE & & $\begin{array}{l}-0.044 \\
(0.120)\end{array}$ & $\begin{array}{l}-0.044 \\
(0.120)\end{array}$ & $\begin{array}{c}-0.052 \\
(0.122)\end{array}$ & $\begin{array}{l}-0.051 \\
(0.121)\end{array}$ & $\begin{array}{l}-0.049 \\
(0.121)\end{array}$ \\
\hline V Good Health & & & $\begin{array}{l}-0.064 \\
(0.123)\end{array}$ & $\begin{array}{c}0.027 \\
(0.130)\end{array}$ & $\begin{array}{c}0.025 \\
(0.130)\end{array}$ & $\begin{array}{c}0.022 \\
(0.130)\end{array}$ \\
\hline Good Health & & & $\begin{array}{l}-0.073 \\
(0.128)\end{array}$ & $\begin{array}{l}-0.030 \\
(0.133)\end{array}$ & $\begin{array}{l}-0.043 \\
(0.133)\end{array}$ & $\begin{array}{l}-0.048 \\
(0.134)\end{array}$ \\
\hline Health Insurance & & & & $\begin{array}{l}0.227^{\dagger} \\
(0.128)\end{array}$ & $\begin{array}{c}0.199 \\
(0.134)\end{array}$ & $\begin{array}{l}0.200 \\
(0.134)\end{array}$ \\
\hline Tot. Health Exp. & & & & $\begin{array}{l}0.001 * * \\
(0.001)\end{array}$ & $\begin{array}{l}0.001 \text { ** } \\
(0.001)\end{array}$ & $\begin{array}{l}0.001 \text { ** } \\
(0.001)\end{array}$ \\
\hline Pension (DC) & & & & & $\begin{array}{c}-0.205^{*} \\
(0.102)\end{array}$ & $\begin{array}{c}-0.206 *{ }^{*} \\
(0.102)\end{array}$ \\
\hline Pension (DB) & & & & & $\begin{array}{l}0.278 \text { ** } \\
(0.098)\end{array}$ & $\begin{array}{l}0.277^{* *} \\
(0.098)\end{array}$ \\
\hline Fin. Wealth & & & & & & $\begin{array}{c}0.086 \\
(0.168)\end{array}$ \\
\hline
\end{tabular}

1. Significance levels : $\quad \dagger: 10 \% \quad *: 5 \% \quad * *: 1 \%$. Significance levels are not displayed for $\alpha$.

2. Omitted categories are Non-Hisp. White, Less than high school Midwest or Other Region, and Poor Health. 
Table 4: WIVES' Simultaneous Duration (Threat point scale=1)

\begin{tabular}{|c|c|c|c|c|c|c|}
\hline Variable & $\begin{array}{c}\text { Coef. } \\
\text { (Std. Err.) }\end{array}$ & $\begin{array}{c}\text { Coef. } \\
\text { (Std. Err.) }\end{array}$ & $\begin{array}{c}\text { Coef. } \\
\text { (Std. Err.) }\end{array}$ & $\begin{array}{c}\text { Coef. } \\
\text { (Std. Err.) }\end{array}$ & $\begin{array}{c}\text { Coef. } \\
\text { (Std. Err.) }\end{array}$ & $\begin{array}{c}\text { Coef. } \\
\text { (Std. Err.) }\end{array}$ \\
\hline$\alpha$ & $\begin{array}{c}1.230 \\
(0.044)\end{array}$ & $\begin{array}{l}1.236 \\
(0.018)\end{array}$ & $\begin{array}{c}1.239 \\
(0.021)\end{array}$ & $\begin{array}{c}1.239 \\
(0.018)\end{array}$ & $\begin{array}{c}1.245 \\
(0.012)\end{array}$ & $\begin{array}{l}1.247 \\
(0.015)\end{array}$ \\
\hline $\log (\delta-1)$ & $\begin{array}{l}-3.427 \\
(0.313)\end{array}$ & $\begin{array}{l}-3.282 \\
(0.084)\end{array}$ & $\begin{array}{c}-3.453 \\
(0.143)\end{array}$ & $\begin{array}{l}-3.440 \\
(0.049)\end{array}$ & $\begin{array}{l}-3.362 \\
(0.336)\end{array}$ & $\begin{array}{l}-3.507 \\
(0.496)\end{array}$ \\
\hline Constant & $\begin{array}{c}-5.834^{* *} \\
(0.161)\end{array}$ & $\begin{array}{c}-5.977^{* *} \\
(0.161)\end{array}$ & $\begin{array}{c}-5.791^{* *} \\
(0.242)\end{array}$ & $\begin{array}{c}-6.012^{* *} \\
(0.326)\end{array}$ & $\begin{array}{c}-5.954^{* *} \\
(0.472)\end{array}$ & $\begin{array}{c}-5.999^{* *} \\
(0.504)\end{array}$ \\
\hline Age Diff. & $\begin{array}{c}-0.080^{\dagger} \\
(0.042)\end{array}$ & $\begin{array}{c}-0.080 \text { ** } \\
(0.017)\end{array}$ & $\begin{array}{c}-0.081^{* *} \\
(0.020)\end{array}$ & $\begin{array}{c}-0.0699^{* *} \\
(0.013)\end{array}$ & $\begin{array}{c}-0.070^{* *} \\
(0.010)\end{array}$ & $\begin{array}{c}-0.070^{* *} \\
(0.015)\end{array}$ \\
\hline Non-Hisp. Black & & $\begin{array}{l}-0.155 \\
(0.146)\end{array}$ & $\begin{array}{c}-0.095 \\
(0.338)\end{array}$ & $\begin{array}{c}-0.045 \\
(0.092)\end{array}$ & $\begin{array}{c}-0.071 \\
(0.334)\end{array}$ & $\begin{array}{l}-0.035 \\
(0.315)\end{array}$ \\
\hline Other race & & $\begin{array}{c}-0.469^{* *} \\
(0.087)\end{array}$ & $\begin{array}{c}-0.498^{* *} \\
(0.172)\end{array}$ & $\begin{array}{c}-0.379 \\
(0.232)\end{array}$ & $\begin{array}{c}-0.402 \\
(0.426)\end{array}$ & $\begin{array}{l}-0.384 \\
(0.412)\end{array}$ \\
\hline Hispanic & & $\begin{array}{c}-0.468^{* *} \\
(0.084)\end{array}$ & $\begin{array}{c}-0.567^{* *} \\
(0.171)\end{array}$ & $\begin{array}{c}-0.4611^{* *} \\
(0.130)\end{array}$ & $\begin{array}{c}-0.487 \\
(0.927)\end{array}$ & $\begin{array}{c}-0.566 \\
(0.422)\end{array}$ \\
\hline High school or GED & & $\begin{array}{l}0.240 * \\
(0.122)\end{array}$ & $\begin{array}{c}0.221 \\
(0.372)\end{array}$ & $\begin{array}{c}0.224^{* *} \\
(0.065)\end{array}$ & $\begin{array}{c}0.188 \\
(0.466)\end{array}$ & $\begin{array}{c}0.092 \\
(0.283)\end{array}$ \\
\hline Some college & & $\begin{array}{c}0.094 \\
(0.188)\end{array}$ & $\begin{array}{c}0.095 \\
(0.361)\end{array}$ & $\begin{array}{c}0.047 \\
(0.125)\end{array}$ & $\begin{array}{c}0.060 \\
(0.463)\end{array}$ & $\begin{array}{c}-0.046 \\
(0.342)\end{array}$ \\
\hline College or above & & $\begin{array}{c}0.225 \\
(0.179)\end{array}$ & $\begin{array}{c}0.243 \\
(0.389)\end{array}$ & $\begin{array}{c}0.277 \\
(0.177)\end{array}$ & $\begin{array}{c}0.154 \\
(0.509)\end{array}$ & $\begin{array}{c}0.054 \\
(0.381)\end{array}$ \\
\hline $\mathrm{NE}$ & & $\begin{array}{c}0.028 \\
(0.232)\end{array}$ & $\begin{array}{c}0.013 \\
(0.280)\end{array}$ & $\begin{array}{c}-0.110 \\
(0.168)\end{array}$ & $\begin{array}{c}-0.104 \\
(0.121)\end{array}$ & $\begin{array}{c}-0.121 \\
(0.408)\end{array}$ \\
\hline $\mathrm{SO}$ & & $\begin{array}{c}0.017 \\
(0.101)\end{array}$ & $\begin{array}{c}0.018 \\
(0.171)\end{array}$ & $\begin{array}{c}0.020 \\
(0.131)\end{array}$ & $\begin{array}{c}-0.020 \\
(0.152)\end{array}$ & $\begin{array}{c}-0.019 \\
(0.255)\end{array}$ \\
\hline WE & & $\begin{array}{l}0.171{ }^{\dagger} \\
(0.102)\end{array}$ & $\begin{array}{l}0.217 * \\
(0.088)\end{array}$ & $\begin{array}{c}0.218 \\
(0.222)\end{array}$ & $\begin{array}{c}0.170 \\
(0.154)\end{array}$ & $\begin{array}{c}0.163 \\
(0.232)\end{array}$ \\
\hline V Good Health & & & $\begin{array}{c}-0.199 \\
(0.357)\end{array}$ & $\begin{array}{c}-0.255 \\
(0.326)\end{array}$ & $\begin{array}{c}-0.261 \\
(0.180)\end{array}$ & $\begin{array}{l}-0.254 \\
(0.376)\end{array}$ \\
\hline Good Health & & & $\begin{array}{c}-0.319 \\
(0.374)\end{array}$ & $\begin{array}{c}-0.365 \\
(0.321)\end{array}$ & $\begin{array}{c}-0.397 * \\
(0.172)\end{array}$ & $\begin{array}{c}-0.295 \\
(0.405)\end{array}$ \\
\hline Health Insurance & & & & $\begin{array}{c}0.304 \\
(0.252)\end{array}$ & $\begin{array}{l}0.229 * \\
(0.106)\end{array}$ & $\begin{array}{c}0.206 \\
(0.212)\end{array}$ \\
\hline Tot. Health Exp. & & & & $\begin{array}{c}0.000 \\
(0.001)\end{array}$ & $\begin{array}{c}0.000 \\
(0.001)\end{array}$ & $\begin{array}{c}0.000 \\
(0.001)\end{array}$ \\
\hline Pension (DC) & & & & & $\begin{array}{c}0.028 \\
(0.231)\end{array}$ & $\begin{array}{c}0.142 \\
(0.328)\end{array}$ \\
\hline Pension (DB) & & & & & $\begin{array}{c}0.366^{* *} \\
(0.123)\end{array}$ & $\begin{array}{l}0.452 * \\
(0.178)\end{array}$ \\
\hline Fin. Wealth & & & & & & $\begin{array}{c}0.351^{* *} \\
(0.042) \\
\end{array}$ \\
\hline
\end{tabular}

1. Significance levels : $\quad \dagger: 10 \% \quad *: 5 \% \quad * *: 1 \%$. Significance levels are not displayed for $\alpha$ nor $\delta$.

2. Omitted categories are Non-Hisp. White, Less than high school Midwest or Other Region, and Poor Health. 
Table 5: HUSBANDS' Simultaneous Duration (Threat point scale=1)

\begin{tabular}{|c|c|c|c|c|c|c|}
\hline Variable & $\begin{array}{c}\text { Coef. } \\
\text { (Std. Err.) }\end{array}$ & $\begin{array}{c}\text { Coef. } \\
\text { (Std. Err.) }\end{array}$ & $\begin{array}{c}\text { Coef. } \\
\text { (Std. Err.) }\end{array}$ & $\begin{array}{c}\text { Coef. } \\
\text { (Std. Err.) }\end{array}$ & $\begin{array}{c}\text { Coef. } \\
\text { (Std. Err.) }\end{array}$ & $\begin{array}{c}\text { Coef. } \\
\text { (Std. Err.) }\end{array}$ \\
\hline$\alpha$ & $\begin{array}{c}1.207 \\
(0.063)\end{array}$ & $\begin{array}{l}1.230 \\
(0.014)\end{array}$ & $\begin{array}{c}1.230 \\
(0.031)\end{array}$ & $\begin{array}{c}1.221 \\
(0.023)\end{array}$ & $\begin{array}{c}1.233 \\
(0.019)\end{array}$ & $\begin{array}{c}1.232 \\
(0.014)\end{array}$ \\
\hline $\log (\delta-1)$ & $\begin{array}{c}-2.541 \\
(0.279)\end{array}$ & $\begin{array}{l}-3.016 \\
(0.130)\end{array}$ & $\begin{array}{l}-3.365 \\
(0.287)\end{array}$ & $\begin{array}{l}-3.365 \\
(0.103)\end{array}$ & $\begin{array}{l}-3.430 \\
(0.301)\end{array}$ & $\begin{array}{c}-3.547 \\
(0.428)\end{array}$ \\
\hline Constant & $\begin{array}{c}-5.498^{* *} \\
(0.194)\end{array}$ & $\begin{array}{c}-5.392^{* *} \\
(0.151)\end{array}$ & $\begin{array}{c}-5.334^{* *} \\
(0.250)\end{array}$ & $\begin{array}{c}-5.654^{* *} \\
(0.212)\end{array}$ & $\begin{array}{c}-5.704^{* *} \\
(0.311)\end{array}$ & $\begin{array}{c}-5.711^{* *} \\
(0.266)\end{array}$ \\
\hline Age Diff. & $\begin{array}{l}0.023^{\dagger} \\
(0.012)\end{array}$ & $\begin{array}{c}0.022^{* *} \\
(0.007)\end{array}$ & $\begin{array}{c}0.023^{* *} \\
(0.011)\end{array}$ & $\begin{array}{c}0.028^{* *} \\
(0.007)\end{array}$ & $\begin{array}{c}0.033^{* *} \\
(0.012)\end{array}$ & $\begin{array}{c}0.027^{* *} \\
(0.010)\end{array}$ \\
\hline Non-Hisp. Black & & $\begin{array}{c}-0.084 \\
(0.140)\end{array}$ & $\begin{array}{c}-0.152 \\
(0.096)\end{array}$ & $\begin{array}{l}-0.126 \\
(0.255)\end{array}$ & $\begin{array}{c}-0.087 \\
(0.265)\end{array}$ & $\begin{array}{c}-0.127 \\
(0.242)\end{array}$ \\
\hline Other race & & $\begin{array}{c}-0.275 * \\
(0.125)\end{array}$ & $\begin{array}{c}-0.327 \\
(0.314)\end{array}$ & $\begin{array}{c}-0.208 \\
(0.129)\end{array}$ & $\begin{array}{c}-0.046 \\
(0.168)\end{array}$ & $\begin{array}{l}-0.066 \\
(0.194)\end{array}$ \\
\hline Hispanic & & $\begin{array}{c}-0.619^{* *} \\
(0.128)\end{array}$ & $\begin{array}{c}-0.667^{* *} \\
(0.224)\end{array}$ & $\begin{array}{c}-0.552^{* *} \\
(0.192)\end{array}$ & $\begin{array}{c}-0.558 * \\
(0.250)\end{array}$ & $\begin{array}{l}-0.523 \\
(0.228)\end{array}$ \\
\hline High school or GED & & $\begin{array}{c}0.059 \\
(0.145)\end{array}$ & $\begin{array}{c}0.049 \\
(0.172)\end{array}$ & $\begin{array}{c}0.045 \\
(0.105)\end{array}$ & $\begin{array}{c}0.066 \\
(0.153)\end{array}$ & $\begin{array}{c}0.067 \\
(0.229)\end{array}$ \\
\hline Some college & & $\begin{array}{c}0.039 \\
(0.149)\end{array}$ & $\begin{array}{c}0.013 \\
(0.183)\end{array}$ & $\begin{array}{c}-0.045 \\
(0.125)\end{array}$ & $\begin{array}{c}-0.046 \\
(0.099)\end{array}$ & $\begin{array}{c}0.007 \\
(0.248)\end{array}$ \\
\hline College or above & & $\begin{array}{c}-0.334 * \\
(0.145)\end{array}$ & $\begin{array}{c}-0.328 * \\
(0.134)\end{array}$ & $\begin{array}{c}-0.245 \\
(0.158)\end{array}$ & $\begin{array}{c}-0.221 \\
(0.146)\end{array}$ & $\begin{array}{l}-0.199 \\
(0.244)\end{array}$ \\
\hline NE & & $\begin{array}{c}0.079 \\
(0.074)\end{array}$ & $\begin{array}{c}0.127 \\
(0.116)\end{array}$ & $\begin{array}{c}0.127 \\
(0.126)\end{array}$ & $\begin{array}{c}0.131 \\
(0.169)\end{array}$ & $\begin{array}{c}0.126 \\
(0.201)\end{array}$ \\
\hline $\mathrm{SO}$ & & $\begin{array}{c}-0.188^{\dagger} \\
(0.106)\end{array}$ & $\begin{array}{c}-0.186 * \\
(0.092)\end{array}$ & $\begin{array}{c}-0.162 \\
(0.111)\end{array}$ & $\begin{array}{c}-0.122 \\
(0.122)\end{array}$ & $\begin{array}{c}-0.172 \\
(0.170)\end{array}$ \\
\hline WE & & $\begin{array}{l}-0.116 \\
(0.143)\end{array}$ & $\begin{array}{c}-0.096 \\
(0.111)\end{array}$ & $\begin{array}{c}0.023 \\
(0.175)\end{array}$ & $\begin{array}{c}-0.095 \\
(0.189)\end{array}$ & $\begin{array}{l}-0.095 \\
(0.186)\end{array}$ \\
\hline V Good Health & & & $\begin{array}{c}-0.061 \\
(0.201)\end{array}$ & $\begin{array}{c}0.029 \\
(0.138)\end{array}$ & $\begin{array}{c}0.027 \\
(0.221)\end{array}$ & $\begin{array}{c}0.022 \\
(0.187)\end{array}$ \\
\hline Good Health & & & $\begin{array}{c}-0.052 \\
(0.218)\end{array}$ & $\begin{array}{c}-0.028 \\
(0.169)\end{array}$ & $\begin{array}{c}-0.032 \\
(0.238)\end{array}$ & $\begin{array}{l}-0.045 \\
(0.201)\end{array}$ \\
\hline Health Insurance & & & & $\begin{array}{c}0.239^{* *} \\
(0.087)\end{array}$ & $\begin{array}{c}0.198 \\
(0.204)\end{array}$ & $\begin{array}{c}0.205 \\
(0.129)\end{array}$ \\
\hline Tot. Health Exp. & & & & $\begin{array}{l}0.001 * \\
(0.001)\end{array}$ & $\begin{array}{l}0.001 * \\
(0.001)\end{array}$ & $\begin{array}{l}0.001 * \\
(0.001)\end{array}$ \\
\hline Pension (DC) & & & & & $\begin{array}{c}-0.156 \\
(0.148)\end{array}$ & $\begin{array}{c}-0.157 \\
(0.163)\end{array}$ \\
\hline Pension (DB) & & & & & $\begin{array}{l}0.241 * \\
(0.116)\end{array}$ & $\begin{array}{l}0.277^{*} \\
(0.139)\end{array}$ \\
\hline Fin. Wealth & & & & & & $\begin{array}{c}0.086 \\
(0.225) \\
\end{array}$ \\
\hline
\end{tabular}

1. Significance levels : $\quad \dagger: 10 \% \quad *: 5 \% \quad * *: 1 \%$. Significance levels are not displayed for $\alpha$ nor $\delta$.

2. Omitted categories are Non-Hisp. White, Less than high school Midwest or Other Region, and Poor Health. 


\section{RECENT WORKING PAPERS FROM THE}

\section{CENTER FOR RETIREMENT RESEARCH AT BOSTON COLLEGE}

Health and Retirement Effects in a Collective Consumption Model of Elderly Households Arthur Lewbel and Shannon Seitz, February 2011

Age Differences in Job Displacement, Job Search, and Reemployment

Richard W. Johnson and Corina Mommaerts, January 2011

The Earnings and Social Security Contributions of Documented and Undocumented Mexican Immigrants

Gary Burtless and Audrey Singer, January 2011

How Important Are Intergenerational Transfers for Baby Boomers?

Alicia H. Munnell, Anthony Webb, Zhenya Karamcheva, and Andrew Eschtruth, January 2011

Effect of Informal Care on Work, Wages, and Wealth

Courtney Harold Van Houtven, Norma B. Coe, and Meghan Skira, December 2010

Recessions, Wealth Destruction, and the Timing of Retirement

Barry P. Bosworth and Gary Burtless, December 2010

Measuring the Spillover to Disability Insurance Due to the Rise in the Full Retirement Age Norma B. Coe and Kelly Haverstick, December 2010

Is the Reduction in Older Workers' Job Tenure a Cause for Concern?

Steven A. Sass and Anthony Webb, December 2010

Accounting for Disability Insurance in the Dynamic Relationship Between Disability Onset and Earnings

Perry Singleton, November 2010

The Treatment of Married Women by the Social Security Retirement Program Andrew G. Biggs, Gayle L. Reznik, and Nada O. Eissa, November 2010

What is the Impact of Foreclosures on Retirement Security?

Irena Dushi, Leora Friedberg, and Anthony Webb, November 2010

Children and Household Utility: Evidence from Kids Flying the Coop

Norma B. Coe and Anthony Webb, November 2010

Overview of the CRR 2009 Retirement Survey

Alicia H. Munnell, Norma B. Coe, Kelly Haverstick, and Steven A. Sass, October 2010

All working papers are available on the Center for Retirement Research website (http://crr.bc.edu) and can be requested by e-mail (crr@bc.edu) or phone (617-552-1762). 